\title{
БАЗОВА ІНФОРМАЦІЙНА ТЕХНОЛОГІЯ ГІБРИДНОГО РОЗПІЗНАВАННЯ ОБРАЗІВ ДЛЯ ОБРОБКИ НЕОДНОРІДНИХ ДАНИХ В СКЛАДНИХ СИСТЕМАХ
}

\author{
O. І. Захожай \\ Східноукрайнський начіональний університет імені Володимира Даля
}

\begin{abstract}
Анотація. Розглядається створення інформаційної технології гібридного розпізнавання образів для обробки даних та підтримки прийняття класифікачійних рішень в складних системах, що характеризуються наявністю великої кількості неоднорідних ознак різної природи виникнення. Така задача ускладнясться тим, що ознаки складної системи мають різну інформативність за різних поточних умов спостереження, а також прояву різнорідних перешкод та викривлень. Розроблена інформаційна технологія дозволяє отримувати результат із апріорно завданим рівнем достовірності через обробку меншої кількості найбільш інформативних ознак. Це додатково мінімізує часову складність обробки.
\end{abstract}

Ключові слова: обробка даних в складних системах, гібридне розпізнавання образів, підвищення достовірності розпізнавання образів, селекиія інформативних ознак, мінімізація часової складності прочесу прийняття рішень.

\section{Вступ}

Методи і алгоритми розпізнавання образів ефективно використовуються для задач обробки даних і прийняття рішень в складних системах, так як не вимагають визначення повної семантики внутрішніх зв'язків та дозволяють здійснювати операції в умовах часткової невизначеності [14]. У випадку неоднорідності даних, коли складна система представляється сукупністю ознак різного характеру інформації (детерміновані, ймовірнісні, логічні, структурні) широкого розповсюдження набули методи комбінованого розпізнавання [5-9].

Гібридне розпізнавання стало подальшим розвитком комбінованого розпізнавання та було запропоновано для прийняття класифікаційних рішень в складних системах, представлених неоднорідними ознаками, які мають різну природу виникнення [10-13]. В ряді робіт, таких як [1416], замість терміну «гібридне розпізнавання» використовується визначення «багатопараметричне комбіноване розпізнавання». Такий підхід використовується для прийняття рішень за умови наявності перешкод і викривлень ознак складної системи, які мають різний прояв та змінюються у часі. Методи гібридного розпізнавання дозволяють визначити різноманітні стратегії обробки неоднорідних даних на основі обробки найбільш інформативної (за поточних умов спостереження) вибірки даних, на які поточні перешкоди мають найменший вплив.

Для прикладного використання гібридного розпізнавання, визначення норм і правил задіян-

(C) Захожай O. I., 2021 ня різноманітних методів обробки, реалізації ситуативно-подійного підходу до стратегії аналізу неоднорідних ознак існує доцільність розробки базової інформаційної технології гібридного розпізнавання образів, що поєднує всі етапи обробки: від отримання сукупності ознак складної системи до прийняття рішення щодо класифікації. Важливою умовою розробки було прагнення отримання універсального рішення, яке дозволить використовувати інформаційну технологію для будь яких складних систем, характеристики якої представляються сукупністю неоднорідних ознак, що мають різну природу виникнення.

\section{1. Аналіз питання та постановка завдання}

Основні аспекти гібридного розпізнавання образів розкриті в роботах $[8,17]$. Сутність такого підходу полягає у представленні складної системи не одним, а сукупністю образів, ознаки яких мають різну природу виникнення i, відповідно, не однаково схильні до впливу різноманітних перешкод і завад. В цьому випадку, одна i та сама перешкода впливаючи на одні групи ознак не буде приводити до викривлення інших груп ознак, що мають іншу природу. Таким чином, створюються умови для здійснення ситуативного визначення сукупності інформативних ознак, які, за поточних зовнішніх умов, дозволяють отримати достовірне класифікаційне рішення щодо стану складної системи. Ситуаційноподійна модель гібридного розпізнавання представляється кортежом [14]:

$$
S E M H P R=\langle P, E C, \text { SICh }, \text { NICh }, C\rangle,
$$


де $P$ - множина образів складної системи, які формуються на основі сукупності інформаційних джерел різної природи виникнення;

$E C$ - множина характеристик зовнішніх умов, що характеризують поточну ситуацію;

SICh - множина стаціонарних характеристик інформативності образів складної системи;

NSICh - множина нестаціонарних характеристик інформативності образів складної системи;

$C$ - множина класів, що характеризують можливі стани складної системи.

Стаціонарні характеристики інформативності $€$ відбиттям точності використаної системи відображення ознак складної системи у просторі образів. Ці характеристики є постійними для використаних засобів реєстрації даних. Нестаціонарні характеристики інформативності, навпаки, змінюються в залежності від поточних зовнішніх умов, тобто, якщо інформаційний канал отримання ознак певного образу знаходиться під значним впливом перешкод, то його нестаціонарна характеристика інформативності буде мати менше значення, ніж характеристика того образу, на який поточна завада не має впливу. Загальна же характеристика інформативності ICh складається 3 двох складових - стаціонарної і нестаціонарної, та використовується для селекції раціональної сукупності інформативних ознак складної системи, які надалі підлягають обробці та формуванню рішення щодо класифікації

$$
I C h_{k}=S I C h_{k} \cdot N \operatorname{SICh}_{k} .
$$

Методика визначення стаціонарних і нестаціонарних характеристик інформативності докладно представлена в [12], метод селекції інформативних ознак запропонований в [18]. Слід зазначити, що характеристики інформативності дозволяють не тільки усунути від подальшої обробки неінформативні дані, але й здійснити ранжування інформативних ознак для визначення раціональної послідовності їх обробки. Ранжування дозволяє визначити чергу обробки, в якій пріоритет у співставленні та формуванні класифікаційного рішення будуть мати образи з найбільшою характеристикою інформативності. Методика формування черги обробки даних при гібридному розпізнаванні представлена в роботі [19]. Згідно неї, ранжування з метою визначення черги обробки здійснюється не тільки по образах складної системи, а й по ознаках цих образів. Пріоритет в оброці отримують ті ознаки, які по відношенню до попереднього циклу аналізу отримали найбільших змін. Методиці визначення послідовності аналізу ознак образів складної системи присвячена робота [20].
Представлений аналіз вказує на наявність моделей і методів обробки неоднорідних даних в складних системах на основі апарату гібридного розпізнавання образів, які дозволяють визначити інформативність образів об'єкту розпізнавання, здійснити селекцію інформативних даних для обробки та прийняття рішення, побудувати чергу 3 цих даних для подальшої обробки. Однак, слід зазначити, що при гібридному розпізнаванні спостерігається значне підвищення кількості ознак складної системи за якими може здійснюватися аналіз і класифікація. При цьому виникає істотна проблема, яка пов'язана 3 наступним протиріччям: 3 одного боку, підвищення кількості ознак, що підлягають співставленню збільшує ймовірність отримання достовірного результату розпізнавання, але $з$ іншого боку, отримання такого результату призводить до додаткових витрат часу і зменшенню актуальності даних. В цьому випадку, отримання достовірного але несвоєчасного класифікаційного рішення знижує його практичну цінність та взагалі призводить до втрати його достовірності для поточного моменту і поточного стану складної системи.

Таким чином, основна задача при розробці базової інформаційної технології гібридного розпізнавання образів полягає у забезпеченні апріорно заданого рівня достовірності розпізнавання при одночасному зменшенні кількості даних, що підлягають співставленню та отриманню класифікаційного рішення. Очевидно, що зменшення кількості співставлень ознак призведе до зменшення часової складності процесу обробки та підвищить оперативність отримання класифікаційного рішення.

\section{2. Вирішення задачі}

Виходячи з поставленої вище задачі, в базовій інформаційній технології (IT) гібридного розпізнавання процес співставлення повинен здійснюватися не до моменту завершення повної обробки усієї сукупності даних, а до моменту отримання апріорно заданого рівня достовірності результату. 3 іншого боку, накладається додаткова умова часового обмеження процесу обробки та прийняття рішення, що вказує на доцільність реалізації IT на основі системи реального часу. Формально ці обмеження можна представити у вигляді:

$$
t_{\min }<t<t_{\max }
$$

де $t$ - деяка часова характеристика, що характеризує тривалість інформаційного процесу, співставлення ознак та отримання результату класифікації; 
$t_{\min }$ i $t_{\max }-$ гранично припустимі значення тривалості інформаційного процесу.

Окрім «жорсткого» реального часу, можна використати умову «м'якого» реального часу, де припустиме певне відхилення від максимального показника тривалості інформаційного процесу на завданий проміжок $\Delta t$

$$
t_{\min }-\Delta t<t<t_{\max }+\Delta t
$$

Таким чином, тривалість обробки даних визначається часом отримання апріорно завданого рівня достовірності, або завершення часу обробки $t_{\text {max. }}$ Для «м'якого» реального часу, якщо апріорно заданий рівень достовірності не досягнутий за проміжок часу $t_{\max }$, то процес обробки може бути продовжений на проміжок часу $\Delta t$.

Також, враховуючи формування черги обробки даних [16], додатковою умовою IT $є$ використання багатозадачності. В системах реального часу використовуються два основних режими багатозадачності [21]: кооперативний і витісняючий.

При кооперативній багатозадачності завдання самі передають управління одна одній за необхідністю. Такий підхід дозволяє досягати високої реактивності системи реального часу на зовнішні події, передбачуваності ії поведінки та ефективного використання апаратних ресурсів.

При витісняючій багатозадачності перемикання завдань здійснюється операційною системою через визначені проміжки часу. Програмне забезпечення, яке працює в умовах витісняючої багатозадачності, має істотну стійкість до помилок, що пов'язані з відмовою обробки одного із завдань. Така ситуація призводить лише до втрат квантів часу, виділених на виконання збійного завдання, але працездатність системи в цілому зберігається.

При гібридному розпізнаванні здійснюється поетапне співставлення інформаційних ознак складної системи і на кожному етапі здійснюється визначення отриманої достовірності. Перехід до наступного етапу порівняння здійснюється за умови, що не було отримано завданого рівня достовірності, а час, визначений для класифікації, ще не вичерпано. При цьому, формується ранжована черга обробки найбільш інформативних ознак складної системи, за якою здійснюється поетапне прийняття рішення. Тому, переваги від використання витісняючої багатозадачності повністю нівелюються тим, що до моменту завершення обробки попередньої ознаки і визначення отриманої достовірності результату класифікації відсутня необхідність переключення на обробку іншої ознаки. Визначення же при цьому най- більш раціональних інтервалів кванту часу, взагалі неможливий, так як час обробки неоднорідних ознак відрізняється. Визначення же кванту часу, на рівні найбільш тривалого процесу співставлення ознаки призведе до перевитрат часу на обробку інших ознак, для яких обраний квант часу $є$ надмірним. Тому, для організації IT гібридного розпізнавання образів доцільне використання кооперативної багатозадачності, коли процес обробки ознаки з черги і визначення поточного рівня достовірності класифікації буде передавати управління процесу обробки наступної ознаки 3 черги, якщо апріорно заданий рівень достовірності не досягнутий, а час, виділений на обробку та класифікацію за умовами «жорсткого» чи «м'якого» реального часу, не вичерпаний. При цьому, кооперативна багатозадачність забезпечить передбачуваність процесу обробки в часовій області, та високу реактивність на зміну вхідних даних, що найбільш актуально для ситуаційного підходу до управляння станом складної системи.

Для реалізації IT гібридного розпізнавання та отримання достовірного рішення за мінімальних часових витрат, у будь який момент часу повинна здійснюватися обробка найбільш інформативних даних. В цьому аспекті, для реалізації базової IT гібридного розпізнавання доцільне використання методу роздільного аналізу ознак [11], який має переваги перед спільним [22] завдяки спрямованості на використання багатозадачності i, насамперед, кооперативної. На рис. 1 наведена схема паралельної обробки та формування черги в IT гібридного розпізнавання образів [16].

Кожен образ відповідає окремому потоку обробки даних. Послідовність обробки образів відповідає зменшенню їх характеристик інформативності ICh. Послідовність співставлення о3нак $\{x\}$ кожного образу визначається відповідно до розроблених метода та інформаційної моделі визначення послідовності даних на основі динаміки їх зміни (тобто ступеня їхньої зміни у порівнянні 3 попереднім циклом класифікації стану складної системи), що докладно представлене в роботі [19].

Також, слід зазначити, що відповідно до екстенсіонально-інтенсіонального методу гібридного розпізнавання [13], на початку черги обробки за кожним образом розміщуються узагальнені характеристики (фрейми), а надалі - деталізовані ознаки (слоти). Згідно представленої черги (див. рис. 1), на кожному етапі порівняння, здійснюється розрахунок достовірності віднесення стану складної системи до кожного класу. Процес обробки може бути завершений на будь 
якому етапі співставлення даних за умови отримання завданого рівня достовірності класифікації або спливання максимального часу, виділеного на обробку.

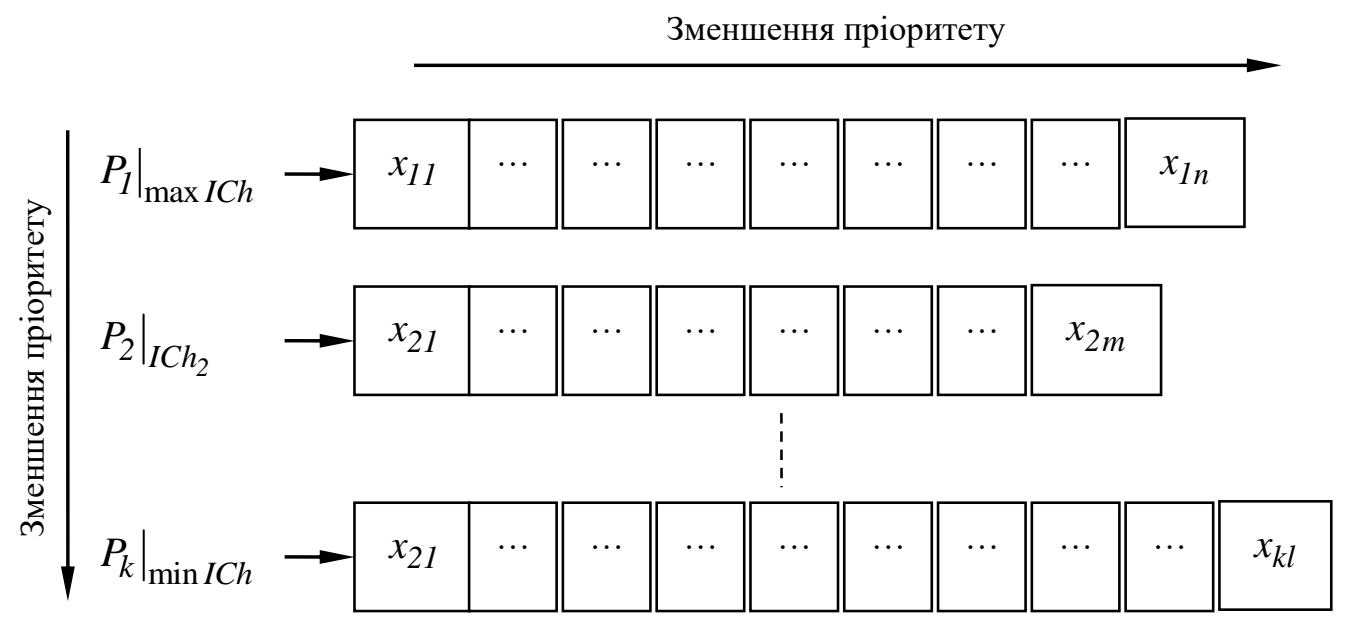

Рис. 1. Формування черги обробки даних при гібридному розпізнаванні

В загальному плані, розроблена базова IT включає 9 етапів, яким передує один апріорний. Апріорний етап виконується тільки підчас створення IT і направлений на визначення стаціонарних характеристик інформативності SICh, що є незмінними в процесі реалізації IT. Апостеріорні етапи здійснюються кожний раз, для кожного циклу обробки неоднорідних даних та гібридного розпізнавання образів. Однак, слід зазначити, що в залежності від поточної ситуації, рівня наявних перешкод і викривлень, деякі етапи можуть пропускатися, якщо бажаний рівень достовірності класифікації досягається на попередніх етапах. Надалі наведений опис кожного етапу розробленої базової IT гібридного розпізнавання образів.

Етап 0. Апріорно визначаються стаціонарні характеристики інформативності SICh кожного інформаційного потоку в складній системі, за якими отримуються образи різної природи виникнення. Враховується точність технічних засобів реєстрації характеристик. $\{S I C h\}$ залишається постійною протягом усіх циклів гібридного розпізнавання. Якщо змінюється структура системи, або замінюються пристрої реєстрації - $\{S I C h\}$ підлягає корекції. Також, на цьому етапі, визначається алфавіт класів, які характеризують можливі стани складної системи.

Етап 1. Реєстрація характеристик стану складної системи та поточних зовнішніх умов.

Етап 2. Нормування вхідних характеристик та визначення множини образів складної системи та зовнішніх для неї умов. (Відповідно до ситуаційно-подійної моделі (1), визначаються $P$ і $E C$ ).

Етап 3. На основі методу визначення інформативності [12], розраховуються нестаціонарні характеристики інформативності NSICh для кожного образа $P$, а також, на основі результатів етапу 0, визначаються загальні характеристики $I C h$, відповідно до (2).

Етап 4. Згідно методу консолідації неоднорідних даних [18] здійснюється селекція інформативних образів складної системи та усуваються від обробки ті образи, що за поточних зовнішніх умов $E C$ не задовольняють заданим значенням ICh.

Етап 5. Відібрані для аналізу образи ранжуються відповідно до їх значень інформативності. Таким чином, формується багатопоточна черга образів для подальшої обробки (на рис. 1, позначена вертикальною стрілкою).

Етап 6. Використовується метод визначення послідовності обробки даних на основі динаміки змін значень ознак складної системи [19]. В результаті, пріоритет в обробці для кожного образу надається ознакам, які мають максимальну динаміку зміни, порівняно з попереднім етапом гібридного аналізу і класифікації. Таким чином, формуються ранжована черга обробки ознак кожного образа (на рис. 1 позначена горизонтальною стрілкою).

Етап 7. Здійснюється екстенсіональний аналіз [13], в якому методом гібридного розпізнавання, основаному на роздільного аналізу та пошуку груп ідентичних класифікацій [23], здійснюється порівняння ознак складної системи. При цьому, за кожним образом сукупності $\{P\}$, обчислюється ступінь подібності до кожного класу 3 множини $\{C\}$

$$
S(P, C)=1-\frac{L}{L_{\max }},
$$

де $L$ - відстань ознаки від репрезентативного значення відповідного класу; $L_{\max }$ - сума відста- 
ней, отриманих по кожному класу на поточному етапі порівняння ознак.

Достовірність класифікації визначається після кожного циклу порівнянь та обраховується 3 використанням міри подібності Хеммінга:

$$
D(C)=\frac{N(C)}{N},
$$

де $N(C)$ - чисельність групи образів 3 ідентичним результатом класифікації до одного й того самого класу $C$.

Відповідно, якщо за одним або групою образів отримується наперед заданий рівень достовірності, то наступний етап 8 пропускається i отриманий варіант класифікації вважається остаточним. Якщо час, виділений для аналізу даних спливає (відповідно до умов систем «жорсткого» i «м'якого» реального часу, описаних вище) або для кожного класу $C$ не отримане задовільне значення $D(C)$ - виконується Етап 8 .

Етап 8 є етапом інтенсіонального аналізу [13], на якому уточнюється результат класифікації, отриманої при екстенсіональному аналізі. Уточнення здійснюється до моменту досягнення апріорно заданого значення $D(C)$. Та класифікація, за якою отримується бажане значення достовірності, вважається остаточною. Якщо за результатами аналізу усіх наявних ознак не отримується завданого рівеня достовірності $D(C)$ або для декількох класів отримуються значення $D(C)$, які відповідають апріорному значенню або час, визначений для аналізу даних та класифікації спливає - здійснюється перехід до етапу 9.

Етап 9. Відповідно до розробленої інформаційної моделі підтримки прийняття рішення у випадку багатоальтернативного результату класифікації [23], формується інформація про групи ідентичних класифікацій 3 розрахованими значеннями отриманої достовірності. Ця інформація надається в ранжованому вигляді, що дозволяє, на основі експертної оцінки, визначити остаточний результат класифікації, який, з великою долею ймовірності, буде визначатися першими значеннями виведеної ранжованої послідовності.

Структурно-логічна послідовність процесів обробки даних, в розробленій базовій інформаційній технології гібридного розпізнавання образів, представлена на рис. 2.

Згідно рис. 2, на основі вхідних даних про стан складної системи формується сукупність образів, ознаки яких мають різну природу виникнення. Також, в цей момент, додатково отримуються дані про зовнішні умови спостереження за об'єктом розпізнавання для подальшого визначення поточного ступеня інформативності кожного образа з сукупності $\{P\}$.
Отримана сукупність образів і характеристик зовнішніх умов, відповідно до ситуаційноподійної моделі гібридного розпізнавання (1), використовується для визначення характеристик інформативності кожного образа за поточних умов спостереження за об'єктом розпізнавання. Характеристика інформативності складається 3 двох складових: SICh (стаціонарної) і NSICh (нестаціонарної). Стаціонарні характеристики інформативності апріорно визначені та витягуються 3 бази знань, а нестаціонарні характеристики визначаються відповідно до поточних зовнішніх умов $E C$.

Надалі, здійснюється селекція образів на основі поточних значень їх характеристик інформативності. Таким чином, від подальшого аналізу та прийняття рішення, усуваються образи, які за поточних умов спостереження за об'єктом розпізнавання мають характеристики менші за попереднє, апріорно задане значення. Таким чином зменшується потужність інформаційного поля подальшого аналізу, що дозволяє зменшити кількість співставлень ознак при прийнятті рішення щодо класифікації.

Виділені для аналізу найбільш інформативні образи підлягають подальшій селекції відповідно до значень їхніх характеристик інформативності. Таким чином, визначається, черга обробки образів складної системи, згідно етапу 5 інформаційної технології.

Надалі здійснюється ранжування ознак образів складної системи, відповідно до етапу 6 інформаційної технології. 3 цією метою, здійснюється визначення динаміки зміни ознак у порівнянні з попереднім циклом розпізнавання. Для цього, з бази знань запитуються збережені на попередньому етапі дані. Так, ознаки, які з попереднього етапу класифікації набули більшої зміни, отримують пріоритет у обробці. Таким чином формується багатопоточна черга обробки даних, де кожен потік містить ознаки кожного з інформативних образів, а ознаки цих образів вибудовуються у відповідності до зменшення ступеня їхньої зміни, відповідно до попереднього циклу розпізнавання.

Сформована черга обробки неоднорідних даних надається для класифікації, в результаті якої визначається відповідність стану складної системи передвизначеним класам $\{C\}$.

Слід зазначити, що при екстенсіональноінтенсіональному аналізі [13], за кожним образом максимальний пріоритет в обробці мають узагальнені, екстенсіональні ознаки, що дозволяє здійснити спробу класифікації з завданим рівнем достовірності на основі мінімальної кількості співставлень. Якщо екстенсіональний аналіз не 
дає збігу класифікації із заданим рівнем достовірності, то надалі здійснюється інтенсіональний аналіз деталізованих ознак, в результаті чого уточняється класифікація. В результаті такої класифікації за методом гібридного розпізнавання на основі пошуку груп ідентичних класифіка-

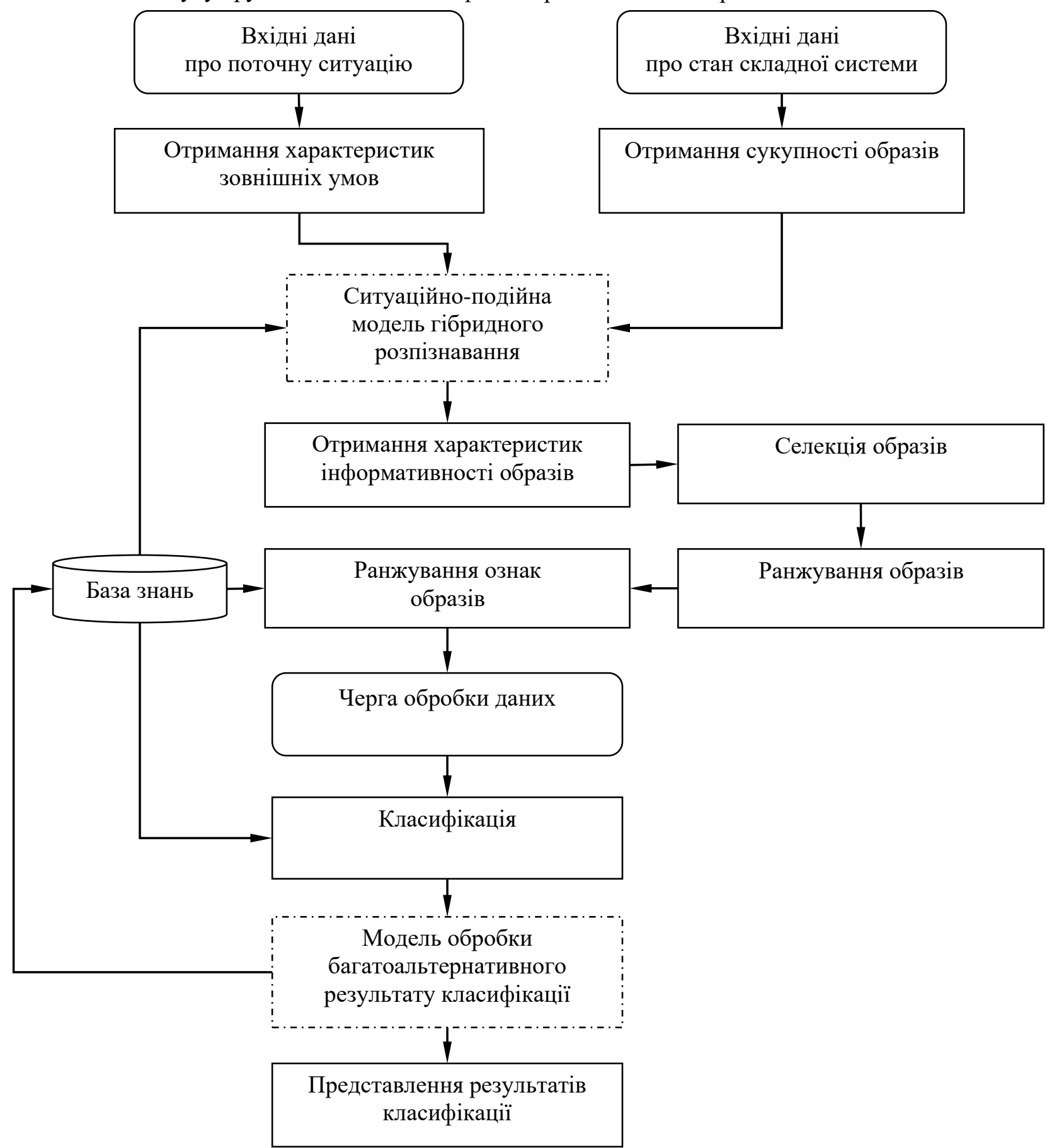

Рис. 2. Структурно-логічна послідовність процесів обробки даних в базовій інформаційній технології гібридного розпізнавання образів

Якщо в результаті класифікації за двома та більше класами отримується апріорно завданий рівень достовірності (чисельність груп ідентичних класифікацій), то такий багатоальтернативний результат обробляється відповідно до інформаційної моделі підтримки прийняття рішення,

цій, процес співставлення ознак здійснюється до моменту часу коли одна чи декілька груп ідентичних класифікацій не досягне апріорно завданої чисельності. Цей процес відповідає етапу 8 представленого вище опису базової IT гібридного розпізнавання образів.

про стан складної системи

Отримання сукупності образів 
мості щодо поточного рівня ознак для того, щоб на наступному етапі ця інформація була запитана для ранжування ознак інформативних образів та корекції черги обробки даних.

\section{Висновки}

Розроблена базова інформаційна технологія гібридного розпізнавання образів дозволяє здійснити консолідовану обробку неоднорідних даних в складних системах, які характеризуються ознаками різної природи виникнення. Ця технологія дозволила поєднати та систематизувати існуючі методи і моделі консолідованої обробки неоднорідних даних засобами гібридного розпізнавання образів з метою отримання достовірного результату в широкому діапазоні змін зовнішніх умов спостереження. При цьому, обробка меншої сукупності але найбільш інформативних даних дозволяє зменшити кількість співставлень ознак при розпізнаванні та знизити час отримання рішення щодо класифікації.

Базова інформаційна технологія гібридного розпізнавання образів може бути використана для організації обробки неоднорідних даних в складних системах будь-якого прикладного застосування, за умови можливості отримання о3нак різної природи виникнення.

Серед актуальних напрямів подальших досліджень можна відзначити наступні:

- розробка прикладних інформаційних технологій гібридного розпізнавання образів для різних застосувань на основі запропонованої базової інформаційної технології

- визначення методики уточнення апріорно заданого алфавіту класів стану складної системи у випадку поганої роз'єднувальності класифікаційних рішень і частого отримання багатоальтернативного результату класифікації.

\section{Список використаної літератури}

1. Liu, Yang-Yu. Control principles of complex systems [Text] / Yang-Yu Liu, AlbertLaszlo Barabasi // Review of modern physics. 2016. - vol. 88. - iss. 3. -58 p.

DOI: 10.1103/RevModPhys.88.035006

2. Kyriakos, G. Vamvoudakis. Control of complex systems [Text] / G. V. Kyriakos, J. Sarangapani. - Elsevier Inc., 2016. - 762 p.

DOI: 10.1016/C2015-0-02422-4

3. Fang, Le. Expectation propagation with stochastic kinetic model in complex interaction systems [Text] / Le Fang, Fan Yang, Wen Dong, Tong Guan, Chunming Qiao // 31st International Conference on Neural Information Processing Systems. - 2017. pp. 2026-2036.
4. Yang, Fan. Optimal Control of Complex Systems through Variational Inference with a Discrete Event Decision Process [Text] / Fan Yang, Bo Liu, Wen Dong // 18th International Conference on Autonomous Agents and Multiagent Systems. 2019. - pp. 296-304.

5. Симанков, В. С. Адаптивное управление сложными системами на основе теории распознавания образов [Текст] / В. С. Симанков, Е. В. Луценко. - Краснодар: Техн. ун-т Кубан. гос. технол. ун-та, 1999. - 318 с.

6. Leigh, W. Forecasting the NYSE composite index with technical analysis, pattern recognizer, neural network, and genetic algorithm: a case study in romantic decision support [Text] / W. Leigh, R. Purvis, J. M. Ragusa // Decision Support Systems. - 2002. - vol. 32. - pp. 361-377.

7. Wen, Q. Automatic stock decision support system based on box theory and SVM algorithm [Text] / Q. Wen, Z. Yang, Y. Song, P. Jia // Expert systems with Applications. - 2010. - vol. 37. pp. 1015-1022.

8. Рябенький, В.М.Комбіновані системи розпізнавання образів [Текст] / В. М. Рябенький, O. I. Захожай // Журнал «Проблеми інформаційних технологій». - 2011. - № 01(009). C. $156-160$.

9. Popovici, Eduard C. Combined use of pattern recognition algorithms for keystroke-based continues authentication system [Text] / Eduard C. Popovici, Liviu A. Stancu, Ovidiu G. Guta, Stefan C. Arseni, Octavian Fratu // 10th International Conference on Communications (COMM). - 2014. - pp. 91-109.

DOI: 10.1109/ICComm.2014.6866686

10.Garcia-Pedrajas, N. Improving multicast pattern recognition by the combination of two strategies [Text] / N. Garcia-Pedrajas, D. Ortiz-Boyer // IEEE Transactions on Pattern Analysis and Machine Intelligence. - 2006. - vol. 28. - pp. 1001-1006.

11.Захожай, О.И. Раздельный анализ информационных признаков в многопараметрических комбинированных системах распознавания образов [Текст] / О. И. Захожай, А. С. Меняйленко, В. А. Лыфарь // Problemele Energeticii Regionale. - Chişinău, Republica Moldova. - 2019. - №1-1(40). - $\quad$ C. 60-68. DOI: 10.5281/zenodo.3239140

12.Захожай, О. І. Критерії визначення інформативності та ранжування образів при прийнятті рішень в багатопараметричних комбінованих системах розпізнавання [Текст] / O. I. Захожай // Журнал «Електротехнічні та комп'ютерні системи». - 2018. - № 27(103). - С. 196-204.

13. Захожай, О. I. Екстенсіонально-інтенсіональний підхід до синтезу інформаційних тех- 
нологій автоматизованої обробки інформації і управління на базі багатопараметричних комбінованих систем розпізнавання образів [Текст] / O. I. Захожай // Журнал «Проблеми інформаційних технологій». - 2015. - № 02(018). C. $106-111$.

14. Zakhozhay, O. I. Situational-event model of the hybrid patterns recognition for heterogeneous data processing in complex systems [Text] / O. I. Zakhozhay // Mathematical modeling in economy. -2019 . - vol. 4. - pp. 16-25.

15.Захожай, О. I. Консолідація даних та прийняття рішень на основі ранжування груп ідентичних класифікацій в гібридних системах розпізнавання [Текст] / О. І. Захожай, В. О. Лифар, В. Г. Іванов // Електротехнічні та комп'ютерні системи. - 2019. - № 31(107) C. 95-103.

16.Захожай, О. I. Визначення черги обробки даних при гібридному розпізнаванні образів [Текст] / O. I. Захожай // Вісник Східноукраїнського національного університету імені Володимира Даля. - 2019. - № 7(255). - С. 111-116.

17.Захожай, О. I. Основні аспекти структурної організації комбінованих систем розпізнавання образів [Текст] / О. І. Захожай, Ю. Е. Паеранд // Вісник ХНТУ. - 2012. - №1(44). C. 221-225.

18.Захожай, О. I. Селекція раціональної сукупності образів в комбінованих системах розпізнавання [Текст] / О. І. Захожай // Журнал «Електротехнічні та комп'ютерні системи». - 2013. № 09(85). - С. 186-192.

19.Меняйленко, О. С. Основи синтезу класифікаторів технічних систем розпізнавання образів 3 використанням моделей емоційних процесів людини [Текст] / О. С. Меняйленко, О. I. Захожай // Науково-технічний журнал «Науковий вісник Національного гірничого університету». - 2015. - № 1(145). - С. 120-126.

20.Захожай, О. І. Визначення черги обробки даних при гібридному розпізнаванні образів [Текст] / О. I. Захожай // Вісник Східноукраїнського національного університету імені Володимира Даля. - 2019. - № 7(255). - С. 111-116.

21. Климентьев, К. Е. Системы реального времени [Текст] / К. Е. Климентьев. - Самара: СГАУ, 2008. - 52 с.

22.Захожай, О. І. Спільний аналіз інформаційних ознак у багатопараметричних комбінованих системах розпізнавання образів [Текст] / О. І. Захожай // Електротехнічні та комп'ютерні системи. - 2018. - № 29(105) - С. 78-86.

23.Захожай, О. І. Прийняття рішень на основі пошуку груп ідентичних класифікацій в багатопараметричних комбінованих системах розпі- знавання образів / О. І. Захожай, В. О. Лифар, O. I. Батурін // Вісник Східноукраїнського національного університету імені Володимира Даля. 2019. - №2 (250). - C. 36-42.

\section{References}

1. Yang-Yu, Liu, Albert-Laszlo, Barabasi, (2016), Control principles of complex systems. Review of modern physics, vol. 88, iss. 3., 58 p. DOI: 10.1103/RevModPhys.88.035006.

2. Kyriakos, G. Vamvoudakis, Sarangapani Jagannathan, (2016), Control of complex systems. Elsevier Inc., 762 p. doi: 10.1016/C2015-0-02422-4

3. Fang, Le, Yang, Fan, Dong, Wen, Guan, Tong, (2017), Expectation propagation with stochastic kinetic model in complex interaction systems. 31st International Conference on Neural Information Processing Systems, pp. 2026-2036.

4. Yang, Fan, Liu, Bo, Dong, Wen, (2019), Optimal Control of Complex Systems through Variational Inference with a Discrete Event Decision Process. 18th International Conference on Autonomous Agents and Multiagent Systems, pp. 296-304.

5. Simankov, V. S., Lutsenko, E. V., (1999), Adaptive management of complex systems based on the theory of pattern recognition [Adaptivnoe upravlenie slozhnymi sistemami na osnove teorii raspoznavaniya obrazov], Techn. univ. Kuban state technol. univ., Krasnodar, 318 p.

6. Leigh, W., Purvis, R., Ragusa, J.M., (2002), Forecasting the NYSE composite index with technical analysis, pattern recognizer, neural network, and genetic algorithm: a case study in romantic decision support. Decision Support Systems, vol. 32, pp. 361-377.

7. Wen, Q., Yang, Z., Song, Y., Jia, P., (2010), Automatic stock decision support system based on box theory and SVM algorithm. Expert systems with Applications, vol. 37, pp. 1015-1022.

8. Ryabenkyi, V. M., Zakhozhay, O. I., (2011), Combined systems of patterns recognition. Problems of information technologies [Kombinovani systemy rozpiznavannia obraziv. Problemy informatsinykh tekhnolohii], vol. 1(009), pp. 156-160.

9. Eduard, C. Popovici, Liviu A. Stancu, Ovidiu, G. Guta, Stefan, C. Arseni, Octavian, Fratu, (2014), Combined use of pattern recognition algorithms for keystroke-based continues authentication system. 10th International Conference on Communications (COMM), pp. 91-109.

DOI: 10.1109/ICComm.2014.6866686

10.Garcia-Pedrajas, N., Ortiz-Boyer, D., (2006), Improving multicast pattern recognition by the combination of two strategies. IEEE Transactions on Pattern Analysis and Machine Intelligence, vol. 28, pp. 1001-1006. 
11.Zakhozhay, O. I., Menyaylenko, A. S., Lyfar, V. A., (2019), Separate Analysis of Informational Signs in Multi-Parametric Combined Patterns Recognition Systems. Problemele Energeticii Regionale [Razdelnii analiz informatsionnykh priznakov v mnogoparametricheskikh kombinirovannykh sistemakh raspoznavaniia obrazov. Problemy regionalnoj energetiki], vol. 1-1(40), pp. 60-68. DOI: 10.5281/zenodo.3239140

12.Zakhozhay, O. I., (2015), Criteria for the determination of informativity and patterns ranking for making decisions in multi-parametric combined recognition systems. Electrotechnical and computer systems [Kriterii vyznachenia informatyvnosti ta ranzhuvania obraziv pry pryjniatti rishen $\mathrm{v}$ bagatoparametrychnykh kombinovanykh systemakh rozpiznavannia. Elektrotekhnichni ta kompiuterni systemy], vol. 27(103), pp. 196-204.

13.Zakhozhay, O. I., (2015), The extensionalintensional approach to the synthesis of information technology of automated data processing and management based on multiparameter combined recognition systems. Journal "Problems of information technologies" [Ekstensionalno-intensionalnii pidkhid do syntezu informatsiinykh tekhnologii avtomatuzovanoi obrobky informatsii i upravlinnia na bazi bagatoparamtrychnykh kombinovanykh system rozpiznavannia obraziv. Jurnal "Problemy informatsiinykh technologii”], 02(018), pp. 106-111.

14.Zakhozhay, O. I., (2019), Situational-event model of the hybrid patterns recognition for heterogeneous data processing in complex systems. Mathematical modeling in economy, vol. 4, pp. 16-25.

15.Zakhozhay, O. I., (2019), The data consolidation and decision making by the ranking of groups with identical classification in hybrid recognition systems. Electrotechnical and computer systems [Konsolidatsia dannykh ta pryinyatya rishen na osnovi ranzhuvania grup identychnykh klasyfikatsii v gibrydnykh systemakh rozpiznavania. Elektrotekhnichni ta kompiuterni systemy], vol. 31(107), pp. 95-103.

16.Zakhozhay, O. I., (2019), The data processing queue definition in hybrid patterns recognition. Bulletin of Volodymyr Dahl East Ukrainian National University [Vyznachennia chergy obrobky dannykh pry gybrydnomu rozpiznavanni obraziv. Visnyk Skhidnoukrainskogo Natsionalnogo Universytetu imeni Volodymyra Dalia], vol. 7(255), pp. 111-116.
17.Zakhozhay, O. I., (2012), Basic aspects of structure organizations combined systems of pattern's recognition. Bulletin KhNTU [Osnovni aspekty strukturnoi organizatsii kombinovanykh system rozpiznavania obraziv. Visnyk KhNTU], vol. 1(44), pp. 221-225.

18.Zakhozhay, O. I., (2013), The rational aggregate selection of informative patterns in the combined recognition systems. Electrotechnical and computer systems [Selektsiia ratsionalnoi sukupnosti obraziv v kombinovanykh systemakh rozpiznavannia. Elektrotekhnichni ta kompiuterni systemy], vol. 09(85), pp. 186-192.

19.Menyailenko, A. S., (2015), Synthesis fundamentals of classifiers for technical systems of patterns recogni-tion with the use of human's models of emotional processes. Scientific and technical journal "Scientific bulletin of National Mining University" [Osnovy syntezu klasyfikatoriv technichnykh system rozpiznavania obraziv $\mathrm{z}$ vykorystaniam modeley emotsiinykh protsesiv lyudyny. Naukovo-Technichniy zhurnal "Naukoviy Visnyk Natsionalnogo Girnychogo Universytetu"], vol. 1(145), pp. 120-126.

20.Zakhozhay, O. I., (2019), The data processing queue definition in hybrid patterns recognition. Bulletin of Volodymyr Dahl East Ukrainian National University [Vyznachennia chergy obrobky pry gibrydnomu rozpiznavanni. Visnyk Skhidnoukrainskogo Natsionalnogo Universytetu imeni Volodymyra Dalia], vol. 7(255), pp. 111-116.

21.Klimentiev, K. E., (2008), The Real-time systems [Sistemy realnogo vremeni], SSAU, Samara, 2008, $52 \mathrm{p}$.

22.Zakhozhay, O. I., (2018), Joint analysis of informational signs in multi-parametric combined patterns recognition systems. Electrotechnical and computer systems [Spilniy analiz informatsiynykh oznak u bagatoparametrychnykh kombinovanykh systemakh rozpiznavaniya obraziv. Elektrotekhnichni ta kompiuterni systemy], vol. 29(105), pp. 78-86.

23.Zakhozhay, O. I., (2019), The decision making by the finding of groups with identical classification in multiparametric combined patterns recognition systems. Bulletin of Volodymyr Dahl East Ukrainian National University [Priynyatya rishen na osnovi poshuku grup identychnykh klasyfikatsiy $\mathrm{v}$ bagatoparametrychnykh kombinovanykh systemakh rozpiznavaniya obraziv. Visnyk Skhidnoukrainskogo Natsionalnogo Universytetu imeni Volodymyra Dalia], vol. 2 (250), pp. 36-42. 


\title{
THE BASE INFORMATION TECHNOLOGY OF HYBRID PATTERNS RECOGNITION FOR HETEROGENEOUS DATA PROCESSING IN COMPLEX SYSTEMS
}

\author{
O. I. Zakhozhai \\ Volodymyr Dahl East Ukrainian National University
}

\begin{abstract}
The article is dedicated to creation of basic information technology of hybrid recognition for data processing and decision-making in complex systems. The main emphasis is placed on systems that are characterized by the presence of a large number of heterogeneous signs with different nature of origin. At the same time, the data processing is complicated by the fact that the patterns of a complex system have different information content under different current observation conditions also the manifestations of heterogeneous interference and distortion. There are methods and models for processing heterogeneous data in complex systems, but there is no systematic approach to developing of hybrid patterns recognition information technology. The article is devoted to solving this problem. The developed information technology allows to obtain a classification solution with a priori level of reliability. It based on processing a smaller number of the most informative signs. This creates possibility to decline time complexity of data processing. The processing is based on queuing heterogeneous data and then searching for groups of identical classifications. In the case of obtaining a multi-alternative result, classification results are ranked in order their reliability for further expert evaluation. Basic information technology, that was created, may be use for develop of the applied information technologies of hybrid patterns recognition for consolidate data processing in different complex systems.
\end{abstract}

Keywords: data processing in complex systems, hybrid patterns recognition, patterns recognition reliability increasing, selection of informative signs, reducing the time complexity of the decision-making process.

\section{БАЗОВАЯ ИНФОРМАЦИОННАЯ ТЕХНОЛОГИЯ ГИБРИДНОГО РАСПОЗНАВАНИЯ ОБРАЗОВ ДЛЯ ОБРАБОТКИ НЕОДНОРОДНЫХ ДАННЫХ В СЛОЖНЫХ СИСТЕМАХ}

\author{
О. И. Захожай \\ Восточноукраинский начиональный университет имени Владимира Даля
}

\begin{abstract}
Аннотация. Рассматривается создание информационной технологии гибридного распознавания для обработки данных и поддержки принятия классификаџионных решений в сложных системах, характеризуюшихся наличием большого количества неоднородных признаков различной природы возникновения. Такая задача усложняется тем, что признаки сложной системы имеют разную информативность при различных текущих условиях наблюдения, а также проявления разнородных помех и искажений. Разработанная информаџионная технология позволяет получать классификаџионное решение с априорно заданным уровнем достоверности через обработку меньшего количества наиболее информативных признаков. Это минимизирует временную сложность обработки.

Ключевые слова: обработка данных в сложных системах, гибридное распознавания образов, повышение достоверности распознавания образов, селекциия информативных признаков, минимизация временной сложности процесса принятия решений.
\end{abstract}

Отримано 11.04.2021

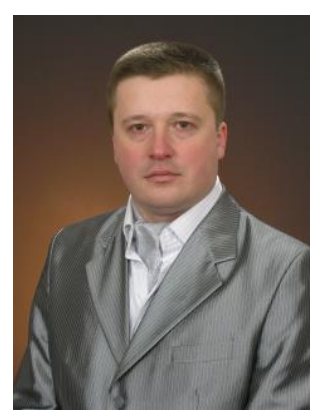

Захожай Олег Ігорович, Східноукраїнський національний університет імені Володимира Даля, доктор технічних наук, доцент, професор кафедри програмування та математики. Просп. Центральний, 59-А, Сєвєродонецьк, Україна, E-mail: zoi@snu.edu.ua, zakhozhay.oleg@gmail.com

Oleh Zakhozhai, Volodymyr Dahl East Ukrainian National University, ScD, associate professor, professor of the Programming and Mathematics department, Central ave., 59-A, Severodonetsk, Ukraine, E-mail: zoi@ snu.edu.ua, zakhozhay.oleg@gmail.com

ORCID ID: 0000-0002-9078-3242 